\title{
Elements of Historical Knowledge Primary Education in Türkiye and United Kingdom (England)
}

\author{
Gülmisâl Emiroğlu \\ Necmettin Erbakan Univercity, Türkiye
}

\begin{abstract}
History and history teaching that is national and cultural ownership providing tool since beginning period, is considered especially with scientific data qualification in $20^{\text {th }}$ century. The history has unarguable place and importance from both aspects at teaching phases. As of today, there are differences regarding to teaching approaches and applications at history teaching. In this respect, analyzing of primary education history teaching in Türkiye and United Kingdom (England) in the frame of textbooks is aimed in this study. The primary education 4 year Social Studies in Türkiye and key stage 2 History texbooks in England will be examined comparably regarding to time, place and person factors of historical knowlegde. Document analyzing method that is one of qualitative research methods will be used at the study.
\end{abstract}

\section{Introduction}

The purpose of this study is to detect the similarities or differences with respect to the place, time, and person factors of historical knowledge in history textbooks thought at schools. The answers of three questions are looked for with this purpose in mind:

1. Are the factors like place, time, and person factors took place in Turkish and English textbooks?

2. Which historical cases took place in Turkish and English textbooks with respect to the place, time, and person factors?

3. What are the similarities and differences between Turkish and English textbooks with respect to their historical place, time, and person factors?

Aforementioned factors are studied both within the frame of a single historical event and within the frame of a comprehensive historical events. Document analyzing method of which one of the qualitative research methods is preferred during this study and the data is analyzed with descriptive analysis method. Two textbooks from each country are studied in concordance with the purpose of this study.

\section{History and the Basic Characteristics of Historical Knowledge}

History in fact is a knowledge that gives the meaning of today with the knowledge of past. It is only possible to understand the evolution of humanity in general and the evolution of nations and societies in particular can only be understood with the education of history since the history is the memory of a nation. Yet it is only possible for a person being to know his place on the planet and the evolution of this placement with all its characteristics is only possible with the knowledge of history and Collingwood also states that one reaches his maturity with the knowledge of history [1]. Consequently the history has a characteristic and prominence of providing knowledge and consciousness on individuals, nations and humanity [2].

The aforementioned prominence of history derives from the characteristics of historical knowledge. If the history is defined as "the chain of events that occurred in the past" then there is no difference for the history from myth, legend, and story. On the other hand, if it is defined as a branch of science, then the past shall be put forward with all its resources [2]. The goal of reviewing documents is to reach to the knowledge of three factors that are place, time, and person and these are the factors that take no place in myth, legend, and story or partly take place in any of them. The history is distinguished from any other myth, history, or story with these three factors that consist in documents and gains a scientific basis. Hence Köstüklü defines history as "a branch of science that reviews past events with the cause and effect relation by tracing their place, time, and principals" [3].

Togan states that the term person in history consists of all society, nation, state, clan, tribe, family and others while trying to paraphrase the 
history definition of Bernheim that is mainly based on person, time, and place and the relations between them [4]. Naturally the person cannot be dealt with without his actions and all the actions of person falls under history. The time and place together consists an inseparable whole while reviewing historical events.

As can be seen, the three factors of place, time, and person consist of a central role that provides the characteristics of history with respect to any other knowledge that happened in the past, and;

- provides information relating to an event in the past,

- provides ability to generate idea relating to the ground of this event,

- provides knowledge that distinguishes both national identity and various other identities,

- constitutes a basis on the singularity of historical events,

- provides a comprehensive historical view to all events occurred in past,

- provides the awareness on historical evolutions and continuation.

The factors of place, time, and person can be treated in two steps in the review of history and education of it. The first step is the review of an individual event and the second one is the review of all events that are correlated. These factors in second stage provide the possibility of widely evaluating these factors with respect to the historical period and geography.

As it is in scientific researches, to achieve a comprehensive and meaningful whole in education it is necessary to identify the basic historical grounds together with the related documents and causality. It is mandatory to provide all place, time, and person factors of a selected historical event in education when a reverse method is preferred. But before this, it is necessary to form minor steps, and stages of events that flow over a main chronological line of events to be able to well provide the events to provide a sense of history that is one of the most prominent purposes of history education [5]. When the factors of place, time, and person are expressly produced in all events, then the goal of providing or awakening sense of history is achieved.

It is obvious that the historical events can only be meaningful when they are reviewed within a cause and effect relation and by taking into care the cultural, social, political, and economic dimensions of these events. But without reviewing all basic knowledge factors of these events, it is not possible to place the historical knowledge and opinions on a stable basis and being aware of the relations between these events [6].

\section{Basic Factors of History in Textbooks}

Turkish and English historical textbooks are reviewed comparatively in this study. In the first stage of this study, the textbooks of each country are reviewed individually with respect to the historical events, time, and person factors. Later these events are reviewed in a whole with respect to place, time, and person factors. At the latest stage of this study the data of Turkish and English textbooks on history that is achieved during the first stage are compared.

\subsection{The Results Achieved Relating to Turkish Textbooks}

The history is thought within the content of Social Studies at the stage of primary education in Türkiye [7]. So the two textbooks of Social Studies thought in 4th class of primary education are reviewed [8] [9]*.

These textbooks of Social Studies in 4th class consist of eight units and there is no private unit that is reserved for history. Only in four units (1st, 2nd, 5 th, and 7th units) there are some history knowledge. Namely, there are 1 historical subject in 1st unit, 2 historical subjects in 2nd unit, 3 historical subjects in 5th unit, and 1 historical subject in 7th unit. Additionally, there are some historical events relating to National Struggle in 2nd and 7th units like Armistice of Mondros, Mustafa Kemal Pasha in Samsun, Mustafa Kemal Pasha in Havza, Amasya, Erzurum, Sivas and Ankara, formal occupation of Istanbul by Allied Powers and adjourn of the chamber of deputies, convening the TBMM within the book of National Ministry of Education; Mustafa Kemal Pasha in Samsun, Congress of Erzurum, Congress of Sivas, convening the TBMM within the book of Evren.

It is possible to summarize all historical knowledge reviewed in these textbooks under two headlines in general: one is the events relating to the National Struggle and the other one is the technological discoveries made in past. So it can be said that these historical textbooks mainly mention about political/ military and technological (culture/civilization) events. There are also some minor subjects on Social Studies and some occasional educational and economic events in these textbooks.

\footnotetext{
* Herein after MEB is used for the books of Kaya, Dağ, Koçak, Yıldırım and Ünal, Evren for Karabıyık and Ertuna books by taking into account their publishers.
} 
3.1.1. Are there any factors of historical events like place, time, and person in Turkish textbooks? The historical events are introduced on time factor within the unit of technological discoveries. These textbooks contain the discoverers of them in general but the places of these events are rarely introduced.

On the contrary, the political, and military events relating to the National Struggle period are substantially introduced with the factors of place, time, and person like Mustafa Kemal Pasha in Samsun, The Congress of Erzurum, The Congress of Sivas, Battle of Sakarya and Pitch Battle of Supreme Military Command, etc. (MEB; Evren). Nevertheless, there is some highly missing information on these subjects within these textbooks and similarly the knowledge relating to person factors of these events are also missing since only Ataturk is introduced in all of these events. So some prominent persons of these events shall also be introduced

Nevertheless there is some missing knowledge about some events within textbooks. Especially the knowledge relating to person factor is highly missing since mainly Ataturk is introduced in all historical events. So some of other prominent actors that take place in these events shall also be introduced to fill this deficiency. But on the other hand, it is also proper to introduce only the leader of some extraordinary historical periods since the nature of such events properly coincides the learning capacity of a child.

The deficiency relating to the basic knowledge factors of historical events in textbooks may be evaluated with respect to the historical event and the effect of understanding such period. While some of such deficiencies make it harder to understand the historical events and historical periods, others do not influence them. If there is an events chain introduced with place, time and person knowledge, then any missing information relating only to one ring of the chain may not influence the student negatively. For instance, the missing time of announcement declared by Mustafa Kemal on the occupation of Istanbul (MEB) does not constitute a deficiency since it is introduced immediately after occupation subject.

Nevertheless, the missing knowledge about an event with respect to its place, time, and person may lead to misunderstanding of this event, may lead to displacement of the event in the right chronological order, and may also lead to insufficient sense of confidence whether this event really happened in the past. For instance, the missing time of the First World War (Evren) may lead to chronologically misplaced events sequence and may lead to an incapability of understanding prominent events of the
National Struggle and the First World War with respect to their cause and effect relation.

As can be observed, there are two important points on the matter of introducing place, time, and person factors in textbooks. One of them is if an event has common place, time, and person factors with the preceding events and this relation can easily be deducted from the text of textbooks and this part of the introduction can easily be removed from the text and no deficiency is observed then this may even prevent duplicate texts. The second point that draws attention is the child's development stage. This development stage is an important factor that defines the learning capacity of a child and needs not to introduce some events and some information relating to this event and points to a need of selection while introducing these events. More clearly, it is needed that the characteristics of a certain period that will lead to a full comprehension of this period shall be selected.

\subsubsection{Which historical events relating to place,} time, and person are introduced in Turkish textbooks? The National Struggle events are introduced within the scale of place, continent, state, and cities in 4th class Social Studies textbooks. The continents of Asia, Europe and Africa, The Ottoman Empire, The Republic of Türkiye, Tripoli (Libya), Thessaloniki, Istanbul (Bosphorous), Galipoli peninsula, Izmir, Merzifon, Eastern Thrace, Mosul, Kocatepe, Ertuğrul Bay are introduced in these textbooks as places (MEB; Evren). Starting from the point of view of knowledge relating to place factor, it may be said that the events that happened within the boundaries of Ottoman Empire and Turkish Republic are introduced.

When the events of National Struggle are taken into account with the factors of time and time, it is detected that the events that took place between 1881-1961/1881-1934 are introduced (MEB; Evren). In fact this period consists of the period of National Struggle and the following events and reaches to the years of 1881, 1911 Tripoli war and 1915 battle of Gallipoli within the frame of life of Ataturk.

Person factor in the historical events referred to Turkish Nation who struggle National Struggle and Ataturk leader of the period. Also the parties of National Struggle, Tripoli War and World War I (such as Greeks, Armenians, French, Italians) as much as rate of their interests are included in the textbooks and the subject of National Struggle have been presented Turkish Nation orients.

When the historical events at the technology subject unit are thought in integrity, the following findings have been reached: It is impossible to mention a certain continent, country or region 
regarding to place information of historical events. Because the place information about the cases were not given so much in the both textbooks. Regarding to person factor, one or a few nation, society or group name was not seen at the technology unit. But giving way of time factor belong to mentioned events is interesting. We have to immediately state that time information of events about mostly technological tools has been provided. Secondly, it was gone in time as much as possible and beginning and development period of technological product etc. has been tried to be presented. For example, the calendar term made based to 5000 / 4000 years ago (MEB; Evren). Therefore, it can be mentioned an approach that gives importance to historical development information at the textbooks.

However, it is seen that this approach that was shown for the technological products is not valid for person and person groups at the same textbooks. Likewise, when the findings about National Struggle period are considered in integrity the most probably, (MEB: 1881-1961 [80 years]; Evren: 1881-1934 [53 years]) historical events are kept limited with 80 years past. Moreover, although the period from Armistice of Mondros to proclamation of Republic has been presented in the structure of history teaching, the events before and after this period have been considered as mutual relations and specific case lack of integrity and as cases showing the conditions. Hence, the time range became too narrow through covering only mentioned period.

This limitation with time factor also created limitation at place and person factors. Therefore the textbooks became limited with Turkish Republic state regarding to place factor, the Turkish nation who lived in Turkish Republic in this time range regarding to person factor. Furthermore, this case is not only special for year 4 textbooks, but also includes content of Social Studies textbooks for years 1,2 , and 3 also year 5 (the content of year 5 textbooks has been enlarged a bit through placing revolutions).

\subsection{Findings about English textbooks}

The history teaching in England is being performed in disciplinary approach in the separate history body via history textbooks. In this study, two textbooks that were prepared in the frame of the $2^{\text {nd }}$ basic phase history program have been examined. One of the mentioned textbooks is about invaders other is about Victoria period [10] [11] ${ }^{*}$.

\footnotetext{
* After that Invaders has been used for Jane, 2006 and Victorians has been used for Triggs, 2006 because of the same publishing house.
}

It has been determined that examined history textbooks include whole history subjects and primarily cultural, political/military and social information have been included information about different aspects of historical information. The subjects at the mentioned textbooks have been presented in right chronological order from past to today.

\subsubsection{Have place, time and person factors of} historical cases been placed in English textbooks? It has been seen that place, time and person factors of historical cases in both of examined textbooks have been presented almost properly despite of some exceptions. Place, time and person factors belong to each period have been given one by one especially at the invaders textbook including a few historical periods that specific groups are effected. The historical cases in the textbook about Victorian period include basic information factors. But general expressions have often been used to state commonality of time and person factors because single period has been considered at the mentioned textbook. For example, 'Victorians' has been used for person factor, 'on throughout Queen Victoria's reign' has been used for time factor. Those statements that are thought to develop history envisagement and understanding about a defined period may not lead a chronological complexity because the time range of mentioned period has been provided at the first page of the book. Mentioned case is valid for missing information factors that were determined at both textbooks.

3.2.2. Which historical events relating to place, time, and person are introduced in English textbooks? When the historical cases at the examined textbooks are examined regarding to time factor, it has been seen that both textbooks include different historical periods. Invaders textbook covers 55 BCE-1066 CE, Victorians textbook covers 18371901 time range. Briefly, when mentioned textbooks are examined regarding to time factor, it can be said that content of history program begins before Christ (beside including another subjects).

Although difference that is seen about time information, examined two textbooks are completely match up with each other. That is to say that the cases realized in Britain have been given place at both textbooks. Thus, as the place information in the textbooks, name of Britain and various settlement places in Britain (such as London, Scotland, Norfolk) are mentioned in the textbooks. Also, different place names were seen as much as concerning rate of Britain (such as Roma, Africa). 
Regarding to person factor, Invaders textbook mentions about Celtics, Schottisches, Romans, Anglo -Saxons, Vikings and Normans, Victorians textbook mentions almost only Britons. If Romans and Vikings are excluded, the basic person factor at both textbook is Britons and cases belong to them have been given.

It can be said that both textbooks are completely about societies composing Britain and today Britons regarding to place, time and person and this shows application of national history.

\subsection{The comparison of Turkish and English Textbooks}

The similarities and differences of historical events in Turkish and English textbooks regarding to place, time and person have been considered in this section. Determined findings belong to both country's examined textbooks have been given in Table 1.

\section{Table 1. The comparison of Turkish and English} textbooks

\begin{tabular}{|c|c|c|}
\hline & Türkiye & England \\
\hline Place & $\begin{array}{l}\text { National Struggle Subjects: } \\
\text { Ottoman State and Turkish } \\
\text { Republic (MEB; Evren) }\end{array}$ & \begin{tabular}{|l|} 
Britain \\
(Invaders and \\
Victorians) \\
\end{tabular} \\
\hline Time & $\begin{array}{l}\text { National Struggle Subjects: } \\
\text { 1881- } 1961 \text { (MEB) ; 1881-1934 } \\
\text { (Evren) } \\
\text { Technology unit: } \\
\text { Antiquity- } 2008 \quad \text { (MEB); } 2002 \\
\text { (Evren) }\end{array}$ & $\begin{array}{l}\text { BCE 55- CE } \\
1066 \\
\text { (Invaders); } \\
1837-1901 \\
\text { (Victorians) } \\
\end{array}$ \\
\hline Person & $\begin{array}{l}\text { National Struggle Subjects: Turks } \\
\text { (MEB; Evren). } \\
\text { Technology Unit:: Pascal, } \\
\text { Leibniz, Hollerith, Morse, Bell, } \\
\text { Braille, Hauy, Baird, French, } \\
\text { South Koreans (MEB); Galileo, } \\
\text { Alman Ruhsa- Knoll, Fludd, Da } \\
\text { Vinci, Verne, Swift, Robinson } \\
\text { (Evren). }\end{array}$ & \begin{tabular}{|l|} 
Britons/ \\
Celtics, \\
Schottisches, \\
Anglo Saxons, \\
Normans \\
(Invaders); \\
Britons/ \\
Victorians \\
(Victorians) \\
\end{tabular} \\
\hline
\end{tabular}

As difference from the previous explanations in the table central and general elements regarding to place, time and person factors have been given place. Therefore, many place and person factors that were determined at the textbooks but don't compose the main are not shown in the table.

As it is understood from the table that, there is both difference and similarity between Turkish and English textbooks. The similarity of both countries' textbooks is about place where historical cases occur. Except a few exemption, nearly all of both Turkish and English textbooks occurred in own land of the mentioned nations where they live today ${ }^{*}$.

Regarding to information on time factor, Turkish and English textbooks, they show difference about time range in which cases occur. This difference that can be considered in serious level is valid for the cases of National Struggle period in Turkish textbooks. Mentioned cases covering in important section of establishment phase of Turkish Republic and its ideology have been occur in too near period to today. On the other hand, English textbooks subject wide time range beginning from $\mathrm{BCE}$ and aligns to beginning of $20^{\text {th }}$ century. This range includes main lines of known Britain and Britons *. Determined time range in English textbooks is also valid for time factor of technology unit in Turkish textbooks. However both of examined Turkish textbooks include development of various technology products from antiquity to $2000 \mathrm{~s}$.

Regarding to person factor, there is both similarity and difference between textbooks of both countries. The examined English textbooks (beside placing Romans and Vikings at invaders) based to Englishness and this points our an approach based to national history centered approach. Turkish textbooks base Turks at the frame of cases belong to National Struggle period that predominates with its political/military history features, but it has been referred to non-Turks scientists and craftsmen in technology points. However chronological setting understand has been adopted while mentioning about this subject and in the regard firstly the changes in the world then the changes in the country have been stated. Whereas the innovations and applications performed by Victorians/English people have been placed instead of developments in the world even at the subjects such as science, urbanism etc at the English textbooks subject to Victorian.

\section{Discussions}

It has been determined that the historical knowledge of examined Turkish and English textbooks have similarities and differences regarding to place, time and person factors.

Both countries' textbooks show similarity at presenting historical events regarding to giving information about place, time and person factors.

\footnotetext{
* The exemption examples about this matter at the textbooks are as follows: Turco-Italian War (MEB; Evren), Attacks to Roma and Invasion (Invaders), Boer War (Victorians).

* Only two textbooks have been examined in this study. It can be thought that there is gab between subjects with reference to mentioned textbooks. But the history curriculum applied in England has content from before Christmas to today in chronological order.
} 
Despite of some missing at Turkish textbooks, generally giving place to basic knowledge factors at Turkish and English textbooks is a positive case. Because mentioned basic information factors composes one of the most important building stones of history teaching [12]. Therefore, it can be stated that those factors are not considered as details that are no need to learn and /or difficult details that may force learning capacity of the student and those information is not waived. Mentioned similarity can be based to adoption of basic structural specifications of history information by textbooks of two countries.

But there are some serious differences between textbooks of two countries. Regarding to place, time and person factors, English textbooks include completely Britain, Britons and historical periods about them (but different place and people are mentioned as far as concerning Britain and Britons). This case point out that English textbooks have national history centered structure [13].

In Turkish textbooks, while 'National Struggle' that is one of two subjects including historical information has been considering at the center of Ottoman/Türkiye/Türk factors; it was seen that the second subject including technological developments based to scientific discovery and technological invention and information about Ottoman/ Türkiye/Türk factors have been given based to 'near environment' and in additional information qualification. However, scientific and technological innovations in Victoria period at the examined English textbooks were not considered in the frame of developments in the world but in the frame of Britain/Britons.

A serious difference regarding to mentioned factors between textbooks of especially two countries occurs when Turkish textbooks are considered as a whole. That is to say, examined English textbooks include historical events wholly subjected Britain/Britons ; on the other hand two subjects including history knowledge have been determined at examined Turkish textbooks. But only one of them (National Struggle) is directly concerning with history science.

The similarities and differences determined between Turkish and English textbooks can be bound to structure of concerned course programs that are applied in those two countries. When we think the history subjects included in the textbooks together with chronological order and teaching period; it can be mentioned that there is integrative history teaching align from past to today at the English textbooks and accordingly at the English program (key stage 2). Because different historical periods relating to Britain / Britons places a teaching learning (key stage) in chronological order [12]. Hence, working areas of history program has been determined as one local history, three English history, one European history (Ancient Greek) and one world history (Old Egypt, Old Sumerian, Assyria, Indus valley, Maya, Benin or Aztec) [14]. As it is seen, four of six subjects are directly concerned with national history. Moreover, Ancient Greek was one of the basic resources of Western civilizations including English people. Based to considered historical period and events, it can be said that history program (key stage2) includes basic information about Britons/English history. Therefore, this structure and features of history teaching in England presents a history perspective and can prepare possibility to develop history conscious.

Social Studies textbooks and programs in Türkiye is limited with determined period (National Struggle) regarding to history subjects. In this case a sole national history subject and assigning short period such as 10 hours to teach this subject for an academic year in Türkiye (year 4) becomes into question [15]. This determined limitation corresponds to result of Doğanay and Sarı's research about Social Studies program is generally lacking in respect of basic information [16]. This limitation about the subject and period may create limitation to teach/learn generally history specifically national history and therefore to teach/learn national identity. At the same time, mentioned scope limitation extremely decreases the possibility to raise 'world wide one' from 'national one' that can be accessed only through knowledge richness [2]. Hence, Social Studies program with its determined basic knowledge missing and deprived from long chronological line structure extremely makes difficult to develop history perspective and conscious.

Mentioned differences between examined course program and textbooks can be bound to adopted purpose of history teaching practically even not theoretically and history teaching understand that was determined through this aspect. From this point of view, it can be said that while history course program and textbooks in England have national history focused structure on the other hand, Social Studies Course Program and textbooks in Türkiye adopted an approach based to current political and social life rather than history/national history teaching. As a result of those approaches, while history teaching shows a disciplinary feature focusing at Britain/Britons in England, history is performed through 'interdisciplinaries' (at primary education phase) understanding in Türkiye [15]. 


\section{Conclusions}

The following results have been concluded at the study in which examined Turkish and English textbooks in the frame of historical cases:

1. The examined Social Studies textbooks are generally similar to each others in large measure regarding to both placing basic information factors, level, historical cases' qualification for place, time, person. Except time factor, English textbooks similar to each other in high level.

2. Regarding to place, time and person factors information belong to historical cases there are obvious differences between textbooks of two countries but there are examples without one or two mentioned factors that will make difficult to understand historical case in Turkish textbooks.

3. It has been seen that examined both textbooks are too different from each other regarding to considered place, time and person factors. In such way that even if English textbooks treated different historical periods regarding to time, it focused Britain and Britons people. Although Turkish textbooks is about an important section of national history (National Struggle), when all of content is considered, it has been seen that no another period of history has been treated and also technological products that are determined through considering development progress frame in the world were not presented Ottoman/Türkiye/Turkish centered.

Consequently, 'national history' understanding that Özalp emphasizes as a forefront feature of new history teaching approach in the world can be expressed as a reason of difference at Turkish and English textbooks and programs about qualification of historical cases [17]. When it is thought that United Kingdom that is one end of this difference is one of the leader countries of global education, this difference became more meaningful. Therefore, perhaps 'national history' understanding and perception can be reconsidered and rethought.

\section{References}

[1] Collingwood, R.G. (1996), Tarih Tasarımı, (Trans. K. Dinçer), (2nd Edition), Gündoğan, Ankara.

[2] Halkın, L.E. (1989), Tarihin Tenkidinin Unsurlarl, (Trans. B. Yediyıldız), Türk Tarih Kurumu, Ankara.

[3] Köstüklü, N. (1998), Sosyal Bilimler ve Tarih Öğretimi, Konya.

[4] Togan, Z.V. (1985), Tarihte Usûl, Enderun, İstanbul (Togan, treats all person activities other than animals as history).
[5] Tekeli, İ. (1998), Tarih Bilinci ve Gençlik, Tarih Vakfı Yurt, İstanbul.

[6] Demircioğlu, İ.H. and Akengin, H. (2006), 'Zaman ve Mekana İlişkin Becerilerin Öğretimi', in C. Öztürk (Ed.) Hayat Bilgisi ve Sosyal Bilgiler Ögretimi, PegemA, Ankara, pp. 219-254.

[7] During the days of preparation for this communiqué, the National Ministry of Education studies on a new regulation that will be effective during school year of 2012-2013.

[8] Kaya, M.K., Dağ, Ö., Koçak, E., Yıldırım, T. and Ünal, M. (2010), Sosyal Bilgiler 4, Devlet Kitapları, İsntanbul.

[9] Karabıyık, E.Ü. and Ertuna, S. (2008), Sosyal Bilgiler 4, Evren, Ankara.

[10] Jane, K. (2006), Invaders, Folens, Buckinghamshire.

[11] Triggs, T.D. (2006), Victorians, Folens, Buckinghamshire.

[12] 'National Curriculum Working Group Final Report (England and Wales)', (1997), in H. Bourdillon (Ed.), Teaching History, Routledge, London.

[13] Aktın, K. (2011), Türkiye, Ingiltere ve ABD sosyal bilgiler/tarih ders kitaplarında yapılandırmacı yaklaşım, II.Dünya Savaşı örneği, (Unpublished $\mathrm{PhD}$ thesis). Marmara Üniversitesi, İstanbul.

[14] History: Key Stages 2, Department for Education, http://www.education.gov.uk (Access Date: 1/8/2012).

[15] İlköğretim Sosyal Bilgiler Dersi Öğretim Programı ve Kılavuzu (4. ve 5. Sinıf), Millî Eğitim Bakanlı̆̆ı, http://ttkb.meb.gov.tr (Access Date: 10/4/2012). 108 hours have been determined for Social Studies Course 4 year level in an academic year; 12 hours of this total period has been assessed.

[16] Doğanay, A and Sarı, M. (2008), 'Öğretmen gözüyle yeni sosyal bilgiler programı: Adana ilinde bir araştırma', İlköğretim Online, 7 (2), pp. 468-484, http://ilkogretimonline.org.tr/vol7say2/v7s2m17.pdf (Access Date: $7 / 11 / 2012)$

[17] Özalp, O. (2000), in Tarih Öğretiminin Yeniden Yapılandırılması, Türkiye Ekonomik ve Toplumsal Tarih Vakfi, İstanbul, pp.4-7. 